\title{
Trace element status on sheep-beef farms in the Raglan-Franklin districts
}

\author{
R.D. LONGHURST ${ }^{1}$, M.F. HAWKE ${ }^{2}$ and M.B. O'CONNOR ${ }^{1}$ \\ ${ }^{1}$ AgResearch, Ruakura Research Centre, Private Bag 3123, Hamilton \\ ${ }^{2}$ AgResearch, c/- FRI, Private Bag 3020, Rotorua
}

\begin{abstract}
During spring 1995, pastoral farms in the RaglanFranklin districts were surveyed to establish their trace element status. The major soil groups of the area were identified and a geographically representative sample of farms within these soil groups sampled for soil and pasture trace element concentrations. In total, 82 sites on 40 farms were sampled. In addition, liver samples from 80 lambs on 20 of these properties were analysed for trace elements during summer of 1995/96. Soil samples were analysed for $\mathrm{Mn}, \mathrm{Cu}$ and $\mathrm{Co}$; pastures were analysed for $\mathrm{Mn}, \mathrm{Fe}, \mathrm{Zn}, \mathrm{Cu}, \mathrm{B}, \mathrm{Mo}, \mathrm{Co}$, Se and I. Lamb livers were analysed for $\mathrm{Cu}$, Se and vitamin $B_{12}$. Survey findings indicated that the Co concentrations in soils, pastures and vitamin $B_{12}$ in lamb livers throughout much of the district were marginal, particularly in the southern area. The two soil groups most at risk were the yellow-brown loams and yellow-brown earths. Farmers are advised to closely monitor their Co status during late spring and to consider their grazing management strategies. Generally, the status of other trace elements was satisfactory.
\end{abstract}

Keywords: lambs, liver vitamin $B_{12}$, pasture cobalt, soil cobalt, soil contamination, soil group, titanium, trace elements

\section{Introduction}

An adequate and balanced trace element status in soils and pastures is essential for maintaining pasture production and animal health in New Zealand. Where a trace element deficiency has been identified on farms and corrective steps taken to remedy the deficiency using drenches, injections, licks or fertiliser, spectacular responses have occurred in the grazing ruminant. Cobalt deficiency, variously described as "Mairoa dopiness" in the King Country (Wright \& Taylor 1931), "bushsickness" in Nelson (Askew \& Dixon 1936) and "Morton Mains disease" in Southland (Dixon 1936) were classic examples.

Conducting a survey can be an effective method of obtaining bench-mark data about the status of soil fertility and animal health. This method has been employed in other areas of the central North Island for identifying the cobalt status of soils and pastures. Cobalt surveys were carried out in the Central Plateau-Bay of Plenty during 1978-80 (Sherrell et al. 1980) and again in 1991 (Hawke et al. 1994) and in the King Country (Hawke et al. 1994).

This survey of Raglan-Franklin districts was commissioned to determine the trace element status of soil, pasture and animals (lambs) on sheep-beef farms over a range of major soil groups in these districts. The only previous information was from a detailed cobalt study on one farm in the south Raglan area (Chapman 1983).

\section{Methods}

Soil type has been identified as an important factor influencing the occurrence of some trace element deficiencies in grazing animals (Fraser 1984). The major soil groups of the area were identified (Bruce 1978) and the relative importance of each ranked. Sheep and beef farmers were contacted with the aim of obtaining a proportionate distribution of soil groups throughout the districts.

The survey was conducted over 40 farms in the Raglan-Franklin districts during September and October 1995. The area covered was from the north-side of Kawhia Harbour to the south-side of Waikato Heads. Field samples were collected from more than one soil group on most farms owing to variability in topography and soil groups; in total, 82 sites were sampled. The soil groups and number of each sampled were: brown granular loam (BGL) 14; brown loam (BL) 5; recent 7; yellow-brown earth (YBE) 27, yellow-brown loam (YBL) 25 and yellow-brown sand (YBS) 4.

Soil and pasture samples were collected along transects at each site. Soil samples $(0-7.5 \mathrm{~cm})$ were analysed for $\mathrm{Mn}, \mathrm{Cu}$ and Co using EDTA-extractable methods described by Forbes (1976). Pasture samples were washed in clean water and analysed for $\mathrm{Mn}, \mathrm{Fe}$, $\mathrm{Zn}, \mathrm{Cu}, \mathrm{B}, \mathrm{Mo}, \mathrm{Co}, \mathrm{Se}$, and I. All pasture samples were analysed for titanium (Ti) to check on soil contamination, as $\mathrm{Ti}$ is not absorbed by the plant (M. Sutton, pers. comm.). Soil and pasture analyses were conducted by the Soil Fertility Service, Ruakura. 
Twenty farmers sent lambs to the meatworks from which four random liver samples were forwarded to the Ruakura Animal Health Laboratory for trace element analysis. Copper was determined in 4 livers and Se and vitamin $\mathrm{B}_{12}$ were determined in 3 livers from each farm.

Soil and pasture data were statistically analysed using ANOVA. The data were $\log$ transformed for statistical analysis with back-transformed means (for soils) or medians (for pastures) reported in tables. The animal data was not analysed.

\section{Results}

\section{Soils (Table 1)}

Soil Mn concentrations were widely distributed, with $20 \%$ of sites above $500 \mathrm{mg} / \mathrm{kg}$. Cu levels were significantly lower on YBE soils than all other soil groups except the YBL. EDTA-extractable Co was below an adequate concentration of $1 \mathrm{mg} / \mathrm{kg}$ air dry soil on $52 \%, 48 \%$ and $36 \%$ of the YBE, YBL and BGL sites respectively.

\section{Pasture (Table 2)}

Pasture Fe concentrations were high, even after washing the herbage, which indicated possible soil contamination. Soil contamination was later confirmed when analyses for $\mathrm{Ti}$ showed a highly significant correlation with $\mathrm{Fe}$.

A wide range of values was found for the various elements with the exception of $\mathrm{Cu}$. Generally, there were no significant differences in trace element concentrations between soil groups. However, Se concentrations on recent soils were significantly lower than on the other soil groups. Pasture Se concentrations of $0.03 \mathrm{mg} / \mathrm{kg} \mathrm{DM}$ (the minimum level) were found on $12 \%$ of sites. The YBL and YBE soils had median pasture Co concentrations of $0.08 \mathrm{mg} / \mathrm{kg}$ DM (the minimum level for sheep). This value was computed after adjustment for Ti concentration to allow for soil contamination.

Generally, pasture concentrations for $\mathrm{Mn}, \mathrm{Zn}, \mathrm{B}$, Mo and I were adequate. However, $21 \%$ of sites had Mo concentrations above $1.5 \mathrm{mg} / \mathrm{kg}$ and $5 \%$ of sites had I concentrations below $0.25 \mathrm{mg} / \mathrm{kg}$ (the minimum level for sheep). Pasture $\mathrm{Zn}$ concentrations on BL soils were significantly lower than for other soil groups.

Table 1 Mean Mn, Cu and Co content of soils ( $\mathrm{mg} / \mathrm{kg}$ EDTAextractable air dry).

\begin{tabular}{lccc}
\hline & $\mathrm{Mn}$ & $\mathrm{Cu}$ & $\mathrm{Co}$ \\
\hline Mean & 303 & 3.9 & 1.7 \\
Range & $19-1680$ & $1.0-9.9$ & $0.2-7.7$ \\
$\quad$ Soil Group & & & \\
BGL & 217 & 3.8 & 1.4 \\
BL & 295 & 4.2 & 1.7 \\
Recent & 458 & 5.0 & 3.3 \\
YBS & 367 & 5.6 & 1.8 \\
YBE & 116 & 2.2 & 0.9 \\
YBL & 168 & 3.7 & 1.0 \\
& $\mathrm{~ns}$ & $* * *$ & $\mathrm{~ns}$ \\
LSR (5\%) & 1.63 & 1.29 & 1.40 \\
\hline
\end{tabular}

LSR $=$ Least significant ratio between YBE and YBL soils

Table 2 The median Mn, Fe, Zn, Cu, B, Mo, Co, Se and I pasture concentrations (mg/kg DM). ${ }^{1}$

\begin{tabular}{|c|c|c|c|c|c|c|c|c|c|}
\hline & $M n$ & $\mathrm{Fe}$ & $\mathrm{Zn}$ & $\mathrm{Cu}$ & B & Mo & Co & $\mathrm{Se}$ & I \\
\hline \multicolumn{9}{|l|}{ Soil Group } & $0.25^{4}$ \\
\hline$B G L$ & 138 & 209 & 32 & 10.3 & 9 & 0.85 & 0.09 & 0.05 & 0.40 \\
\hline $\mathrm{BL}$ & 190 & 217 & 26 & 9.8 & 8 & 0.72 & 0.11 & 0.05 & 0.51 \\
\hline Recent & 225 & 200 & 37 & 10.1 & 9 & 1.22 & 0.14 & 0.03 & 0.42 \\
\hline YBS & 178 & 313 & 36 & 9.6 & 8 & 0.76 & 0.14 & 0.06 & 0.55 \\
\hline YBE & 160 & 222 & 38 & 10.5 & 9 & 1.01 & 0.08 & 0.06 & 0.41 \\
\hline \multirow[t]{2}{*}{ YBL } & 178 & 231 & 36 & 10.2 & 8 & 0.91 & 0.08 & 0.06 & 0.57 \\
\hline & ns & $*$ & $*$ & ns & ns & ns & * & $*$ & ns \\
\hline LSD (5\%) & 70 & & & 1.8 & 2 & & & & \\
\hline $\operatorname{LSR}(5 \%)^{5}$ & & 1.30 & 1.19 & & & 2.72 & 1.54 & 1.27 & 1.81 \\
\hline \multicolumn{10}{|c|}{1 Adjusted for soil contamination using titanium concentration of $20 \mathrm{mg} / \mathrm{kg} \mathrm{DM}$. } \\
\hline \multicolumn{10}{|c|}{2 Minimum $=$ minimum dietary requirements for sheep (MAF, 1988) } \\
\hline \multicolumn{10}{|c|}{3 NK $=$ not known } \\
\hline \multicolumn{10}{|c|}{4 Minimum $=$ minimum dietary iodine requirement for sheep $($ Grace, 1994$)$} \\
\hline \multicolumn{10}{|c|}{5 LSR = least significant ratio between YBE and YBL soils } \\
\hline
\end{tabular}


Animal - lamb livers (Table 3)

Although the $\mathrm{Cu}$ and $\mathrm{Se}$ concentrations were adequate, $22 \%$ and $5 \%$ ofvitamin $B_{12}$ samples were in the marginal (< $375 \mathrm{nmol} / \mathrm{kg}$ ) and low $(<280 \mathrm{nmol} / \mathrm{kg}$ ) ranges respectively (MAF 1988). Only $8 \%$ of the farmers gave their lambs vitamin $\mathbf{B}_{12}$ injections.

Table 3 Trace element status of lamb livers $(\%$ of total sampled).

\begin{tabular}{lccc}
\hline & Copper & Selenium & Vitamin $\mathrm{B}_{12}$ \\
\hline Low & 1 & 0 & 27 \\
Adequate & 94 & 100 & 70 \\
High & 5 & 0 & 3 \\
\hline
\end{tabular}

1 Adequate range is $95-3000 \mu \mathrm{mol} / \mathrm{kg}$ for $\mathrm{Cu} ; 450-10000 \mathrm{nmol} / \mathrm{kg}$ for Se; $375-1000 \mathrm{nmol} / \mathrm{kg}$ for vitamin $B_{12}$ (MAF 1988).

\section{Discussion}

\section{Iron and titanium}

Survey results showed that pasture Fe concentrations were very high (104-3674 $\mathrm{mg} / \mathrm{kg}$ DM). Similar concentrations (1 1 I-3850 $\mathrm{mg} / \mathrm{kg}$ ) had been found (but on unwashed pasture) between May and August during studies at Ruakura (Campbell et al. 1974). Because seasonal variation studies have shown elevated Fe levels in late winter-early spring (Metson et al. 1979; Grace \& Clark 199 1), it was important to determine whether the high $\mathrm{Fe}$ concentrations were peculiar to this district with an iron-sand coastline or due, despite washing, to soil contamination. There are also stock health implications, for example, high $\mathrm{Fe}$ intakes in diets can reduce the absorption of $\mathrm{Cu}$ in sheep and cattle (Grace 1994). The Ti analyses clearly confirmed that pasture samples were contaminated with soil. Because soil usually contains higher concentrations than pasture there is an enrichment factor associated with soil contamination. Healy et al. (1973) found that pasture (especially clover) concentrations of $\mathrm{Co}$, Se and I to be greatly enriched by soil contamination.

\section{Copper}

Results showed that both soil and pasture $\mathrm{Cu}$ concentrations were adequate. Copper was topdressed on $5 \%$ of farms while $40 \%$ of farmers treated their stock with some form of $\mathrm{Cu}$ supplement (through injections or bolus applications). Overall, the $\mathrm{Cu}$ status of the district appears to be adequate; however, caution would be required on some farms as high pasture Mo concentrations in the presence of sulphur can decrease $\mathrm{Cu}$ absorption (Cornforth 1980).

\section{Cobalt}

Survey results indicate that Co is the trace element that deserves the most attention in this district. The critical concentration of $\mathrm{Co}$ in pasture for sheep dietary requirements is $0.08 \mathrm{mg} / \mathrm{kg}$ DM (Clark \& Millar 1983). Findings from previous Co surveys have found plant Co to be positively correlated to EDTA-extractable soil Co (Hawke et al. 1994). Recent data from 560 sheepbeef farms throughout NZ showed that for an $80 \%$ probability of achieving $0.08 \mathrm{mg} / \mathrm{kg}$ Co in pasture, the EDTA-extractable Co concentration required was between 0.75 and $1.7 \mathrm{mg} / \mathrm{kg}$, depending on the soil group (O'Connor et al. 1997). In the present survey, analyses suggest that for an $80 \%$ probability of pasture achieving a Co concentration of $0.08 \mathrm{mg} / \mathrm{kg}$ DM, EDTAextractable soil Co needs to be at least $1.5 \mathrm{mg} / \mathrm{kg}$ air dried soil (Figure 1). This concentration is necessary where the soil Mn was $190 \mathrm{mg} / \mathrm{kg}$ (the mean). Higher soil Mn levels would require higher soil Co status (Adams et al. 1969).

Figure 1 Percentage probability that pasture Co exceeds 0.08 $\mathrm{mg} / \mathrm{kg}$ DM for a given soil Co value and a soil Mn value of $190 \mathrm{mg} / \mathrm{kg}$

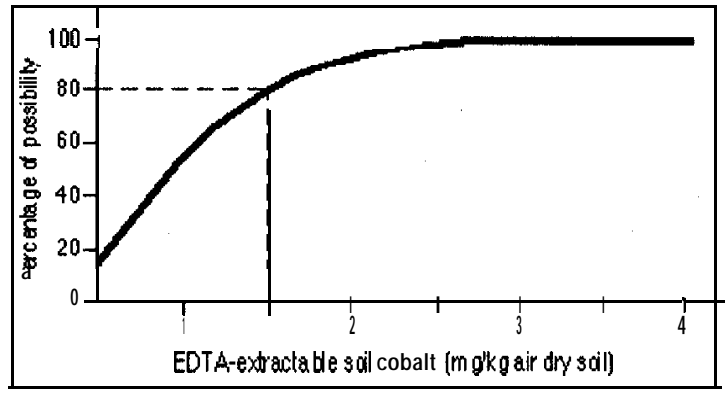

Cobalt problems are most likely to be experienced on the YBL and YBE soils particularly in the southern area of the district. The YBL soils are derived from Mairoa ash which was classified as severely Co deficient (Andrews 1971). Also, Chapman (1983) reported Co as deficient in a YBL soil in the south Raglan area. However, BL soils in this area have higher Co levels than YBL soils as found by Chapman (1983) and this survey (Table 1). A management strategy for alleviating Co shortages during the critical spring and summer months suggested by Chapman (1983) could be to rotate grazing stock between YBL and BL areas where the two soil groups occur on the same property. Other proven methods of control include applying Co in the fertiliser (long term) or using vitamin $\mathrm{B}_{12}$ injections (short term).

Pasture Co studies on seasonal variation have indicated lower values going into the summer period 
(Grace \& Clark 1991), while plant species and stage of growth (Mitchell 1945; Andrews 1971) can also contribute to yearly fluctuations. This survey highlights the difficulty of determining the "true" Co content of pasture during early spring. The unadjusted median concentrations for the YBL and YBE soils were 0.12 and $0.23 \mathrm{mg} / \mathrm{kg} \mathrm{DM}$ respectively, compared with medians of $0.08 \mathrm{mg} / \mathrm{kg}$ DM adjusted for soil contamination. Soil contamination of pasture is recognised as a source of Co to grazing stock and can occur as a result of animal treading or soil splash on short pasture during heavy rain. Pasture height becomes a crucial factor in determining Co concentrations: the shorter the pasture the more likely it is to have soil contamination. Andrews et al. (1958) induced Co deficiency in weaned lambs at low grazing intensity on marginally deficient pasture compared with heavy grazing intensity. Pasture samples for Co should also include $\mathrm{Fe}$ to indicate possible soil contamination. Pasture $\mathrm{Fe}$ concentrations above $250 \mathrm{mg} / \mathrm{kg}$ are considered to be contaminated by soil (G. Renshaw, pers. comm.) The most conclusive test for farmers to undertake on lambs is vitamin $B_{12}$ analysis on serum and/or liver samples.

Topdressing pasture with Co is the most effective long-term strategy for raising pasture Co. However, relatively few farmers in this survey applied Co fertiliser, some $15 \%$ and $13 \%$ of farms receiving regular and occasional topdressings respectively. The EDTAextractable Co soil test could be used to determine the quantity of Co fertiliser required to raise soil Co reserves to the required level (O'Connor et al. 1997).

\section{Selenium}

The Se concentrations of lamb livers were all in the adequate range. However, Se pasture concentrations on recent soils (river flats) were at the minimum dietary Se requirement for sheep. As the recent soils comprise such a small area on farms in the district, rotating livestock between river flats and rolling paddocks would normally overcome any potential Se problems.

\section{Summary}

Survey findings indicated that the Co status throughout much of the district was marginal, particularly in the southern area. This was shown in soil, pasture and lamb liver samples. The two soil groups most at risk were the yellow-brown loams (ash soils) and yellow-brown earths (mudstone, sandstone soils). Farmers on suspect soils are advised to monitor their Co status in late spring to identify whether Co supplementation of animals is necessary. Iron analyses should be included to determine likely soil contamination. A further management practice of some farmers would be to ensure that livestock, particularly the young, are grazed alternately between soil groups with high/low Co status.

Generally, the status of the other trace elements analysed was satisfactory. The high $\mathrm{Fe}$ status of the district should be recognised.

\section{ACKNOWLEDGEMENTS}

The authors wish to thank the following for their assistance: the participating farmers for their cooperation; the veterinarians at the Raglan, Northern Waikato and Franklin practices; Richard Chapman, University of Waikato; John Waller for statistical analysis and Tom Gee for field assistance. BOP Fertiliser Ltd and the C Alma Baker Trust for funding the survey.

\section{REFERENCES}

Adams, S.N.; Honeysett, J.L.; Tiller, K.G.; Norrish, K. 1969. Factors controlling the increase of cobalt in plants following the addition of a cobalt fertiliser. Australian journal of soil research 7: 29-42.

Andrews, E.D. 1971. Cobalt deficiency in sheep and cattle. New Zealand Department of Agriculture Bulletin 180. Wellington, NZ Government Printer.

Andrews, E.D., Stephenson, B.J., Anderson, J.P., Faithful, W.C. 1958. The effect of length of pasture on cobalt deficiency in lambs. New Zealand journal of agricultural research 1: 125-139.

Askew, H.O.; Dixon, J.K. 1936 The importance of cobalt in the treatment of certain stock ailments in the South Island, New Zealand. New Zealand journal of science and technology 26: 73-92.

Bruce, J.G. 1978. Soils of Raglan County, South Auckland. Soil Bureau Bulletin 41. 102 p.

Campbell, A.G.; Coup, M.R.; Bishop, W.H.; Wright, D.E. 1974. Effect of elevated iron intake on copper status of grazing cattle. New Zealand journal of agricultural research 17: 393-399.

Chapman, R. 1983. Soil cobalt and agricultural implications in South Raglan County, New Zealand. Thesis study, 149 pp. University of Waikato, Hamilton.

Clark, R.G.; Millar, K.R. 1983. Cobalt. The mineral requirements of grazing ruminants. Ed. N.D. Grace. New Zealand Society of Animal Production: 150 pp.

Cornforth, I.S. 1980. The copper status of sheep. In Sheep and cattle nutrition, Agricultural Research Division, MAF. 151 pp.

Dixon, J.K. 1936. Investigations on a sheep ailment in Southland. New Zealand journal of science and technology 17: 600-619. 
Forbes, E.A. 1976. Cobalt, copper, and zinc in yellowbrown pumice soils under grazed permanent pasture. New Zealand journal of agricultural research 19: 153-164.

Fraser, A.J. 1984. The relationship between New Zealand's geology and soils and trace element deficiencies in grazing animals. Proceedings of the New Zealand Society of Animal Production 44: 125133.

Grace, N.D.; Clark, R.G. 1991. Trace element requirements, diagnosis and prevention of deficiencies in sheep and cattle. Proceedings of the Seventh International Symposium on Ruminant Physiology. Academic Press Inc.

Grace, N.D. 1994. Managing trace element deficiencies, Palmerston North, New Zealand Pastoral Agricultural Research Institute Ltd. 70 pp.

Hawke, M.F.; O'Connor, M.B.; Johnston, T.J.M.; Waller, J.E.; Addison, B. 1994. Monitoring cobalt status: experiences in the central North Island. Proceedings of the New Zealand Grassland Association 56: 249-254.

Healy, W.B., Rankin, P.C., Watts, H.M. 1973. Effect of soil contamination on the element composition of herbage. New Zealand journal of agricultural research 17: 59-61.

MAF 1988. Optigrow animal health profiles: A guide for veterinarians. Complied by R.S.Ellison and C Feyter, Ruakura.

Metson, A.J.; Gibson, E.J.; Hunt, J.L. 1979. Seasonal variation in chemical composition of pasture III. Silicon, aluminum, iron, zinc, copper, and manganese. New Zealand journal of agricultural research 22: 309-318.

Mitchell, R.L. 1945. Cobalt and nickel in soils and plants. Soil science, 60: 63-70.

O'Connor, M.B.; Waller, J.; Morton, J.; Hawke, M.F. 1997. Utilising soil and plant analysis for the prevention of cobalt deficiency in New Zealand. Proceedings of XV111 International Grassland Congress, Saskatoon, Canada June 8-19 (in press).

Sherrell, C.G.; Pervical, N.S.; Poole, P.R. 1980. Reducing cobalt applications on pumice soils. Proceedings Ruakura Farmers Conference 32: 71-77.

Wright, C.M.; Taylor, N.H. 1931. A successful experiment on sheep-sick country in Mairoa district. New Zealand journal of science and technology 13: $57-75$. 
